$$
b=3 \text { のとき } \quad C=\frac{\left(K^{\prime} \mid K\right)_{b=3}}{\left(K^{\prime} \mid K\right)_{b=1}}
$$

で計算すれば数平均重合度から $[\eta]^{25^{\circ}}$ C る。Fig. 5 はこのようにして計算した $[\eta]$ の理論值を Fig. 2 と同一実験条件で得られたポリマーの粘度とを比 較したもので良い一致が得られる。

すなわち水が系内にあるような重合系で $b=2$ 以上の とき，もはや $[\eta]=K \bar{P}_{n}{ }^{a}$ の $K$ が一定とならず $n_{w}$ の小 さいときは大きな值でしだいに小となる。その傾向は, 量平均重合度に関し示した Fig. 4 と全く類似している。

\section{3. 結言}

ポリカプラミド-水-多塩基酸系では multichain の分
子と singlechain の分子が混在するが，重合度，粘度な どについて理論的取扱がある程度可能となった。

付 記：本報告の大要は昭和 30 年 11 月 7 日, 日本化学 会東海支部大会において発表した。ご指導および発表許可を賜 わった東洋レーヨン(株) 名古屋工場長菊川康雄氏, 研究部長小 林治男博士に謝意在表します。

\section{文献}

1) O. Fukumoto: J. Polymer Sci., 22, 263(1956)

2) 福本 修: 高化, 18, 19(1961)

3) P. J. Flory: J. Am. Chem. Soc., 70, 2709 (1948)

4) 由本碩亮: 未発表

\title{
Equilibria Between Polycapramide and Water
}

\section{Theoretical Treatment on the Degree of Polymerization, the Melt Viscosity and the Solution Viscosity of Multi-chain Polycapramide \\ By Osamu Fukumoto}

\begin{abstract}
A theory has been developed on the relationships among temperature, vapor pressure of water and the number average or weight average degree of polymerization or melt viscosity of multi-chain polycapramide. The results obtained is summerized as follows. When viscosity stabilizer with two or more functional groups is used, the molecular weight distribution of this polymer becomes very sharp. As the relationship obtained previously between $\bar{P}_{n}$ and $[\eta]$ can not be applied to this case, a revised expression has been introduced, which is in good agreement with experimental results. When temperature, vapor pressure of water and the amount of stabilizer are kept constant, the number average degree of polymerization increases, as the functional degree of the stabilizer increases, and at lower water vapor pressures, the weight average degree of polymerization, the melt viscosity and the solution viscosity decrease. A higher water vapor pressure, however, the latter three quantities depends reversely on the functional degree of the stabilizer. When two functional stabilizers are used, a rough agreement has been shown between the theory and the experimental results on the number average degree of polymerization and the solution viscosity.
\end{abstract}

\section{第 4 報 ナイロン 6 , ナイロン 610 , ナイロン 11 の比較 (1960 年 8 月 9 日受理)}

福本修

\begin{abstract}
要 旨溶融したナイロン $6,610,11$ などの水蒸気圧と水の平衡溶解量の関倸を測定した。こ机らの 測定値から比較的低温度ではアミド間の水素結合がかなり残存しているが, 高温度 $\left(256^{\circ} \mathrm{C}\right)$ になるとアミド間 の水素結合が相当少なくなっているよ5に思われる。ナイロン 610 に関し末端基を測定し縮合の平衡定数を求 めた。平衡定数は温度が高いとき小さくなり，低温度では大きい。この結果はポリカプラミドに関して求めた 傾向と同様であり，また平衡定数も大体類似した数値となった。
\end{abstract}

1. 緒言

前報までで水および $\varepsilon$ カプロラクタムの溶融ポリカ
プラミドに対する溶解度とそれらの蒸気圧の関係, 粘度, 末端基などを測定することにより，ポリカプラミド製造 の際の諸関倸を明らかにすることができた ${ }^{1)}$ 。固相ポリ 
アミドの水分子の吸着に関しては星野, 由本の研究2)を はじめ 2 3 の研究があるが, 溶融状態のポリアミドに 対する水の溶解性に関する研究はないようである。一般 にポリマーの結晶化度は水分子の吸着に大いに影響する といわれているが, 溶融状態では常識的にかかる領域は 存在しないものと仮定されるから，アミド間の水素結合 の程度のみがこの場合因子として入ってくるものと想像 される。筆者は比較的融点の低いナイロン 6 , ナイロン 610, ナイロン11 を選び, それらに対する水の溶解性に ついて検討し，またナイロン610 の鎖状分子間の平衡に 関しても若干の実験を行なった。

\section{2. 実験および考察}

\section{1 水の溶解度について}

$225,235,256^{\circ} \mathrm{C}$ で種々の水蒸気圧に扔ける溶融ポリ マーに対する水の溶解度を測定したのが Fig. 1 3 であ る。この実験で用いたナイロン 6 は水溶成分を十分除去 した後，まだラク夕ムが十分に生成しないような条件で

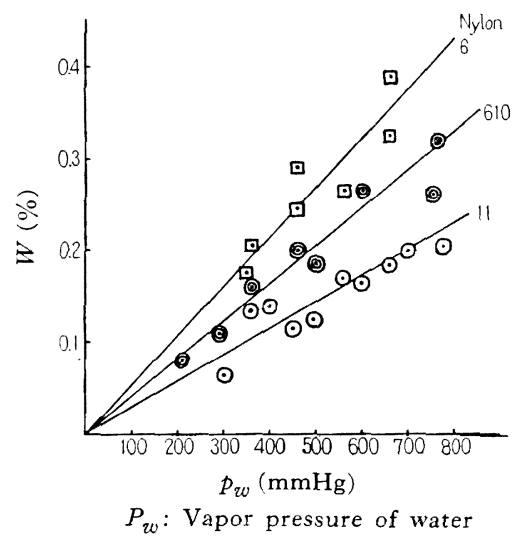

Fig. 1 Solubility of water (in weight percent), in molten Nylon 6,610 and 11 against its vapor pressure at $235^{\circ} \mathrm{C}$

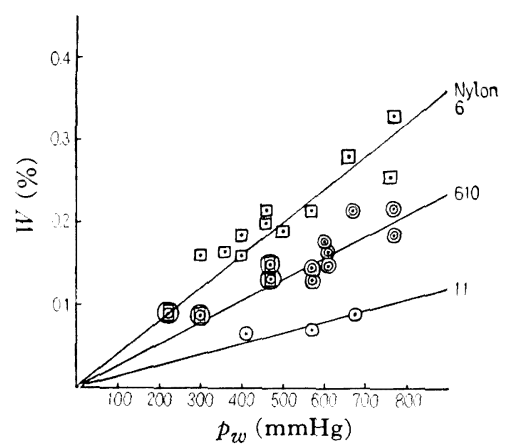

Fig. 2 Solubility of water (in weight percent) in molten Nylon 6,610 and 11 'against its vapor pressure at $256^{\circ} \mathrm{C}$

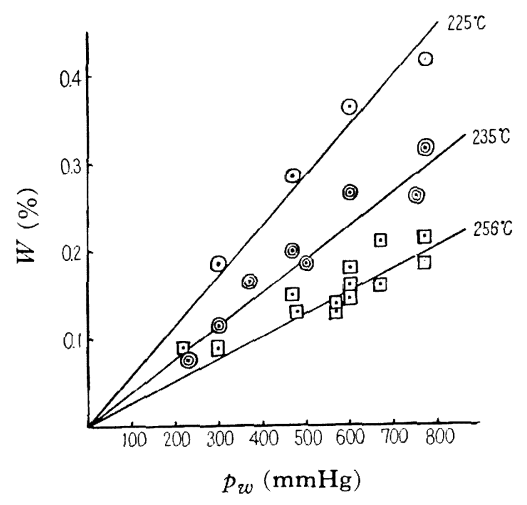

Fig. 3 Solubility of water (in weight percent) in molten Nylon 11 against its vapor pressure

水分を測定した。ポリマーと水との接触時間は 5 時間で 前報 ${ }^{3)}$ の方法と全く同様な操作で行なった。760 $\mathrm{mmHg}$, $400 \mathrm{mmHg}, 200 \mathrm{mmHg}$ の水蒸気圧下 $259^{\circ} \mathrm{C}$ で 5 時間 ポリカプラミドを接触させる際, 生成したカプロラクタ ムは $2.10,1.53$ および $0.79 \%$ であり, その蒸気圧は無 視できよう。

測定值は図に示すように, 従来のポリカプラミドの測 定值と同様 Henry の法則に従らような直線で連結しう る。最近の報告によると， $\varepsilon$-カプロラクタムは溶液状態 において大部分が次図のように2 分子が水素結合して安 定化していることが確かめられだ)。<smiles></smiles>

このようにヒーカプロラクタムのアミドはシス型にな っているが, 一方鎖状分子は一般にトランス型といわれ ている。したがって，かかるシス型とトランス型のアミ ドに対し水分子が水素結合する容易さが異なるから，ポ リカプラミド中に溶存するカプロラクタムの量は水の溶 解度にかなり関係してくるものと思われる。溶融状態の 鎖状分子がある程度の水素結合をいまだに保有している 上考えることは，たとえば水が液体においてもある程度 の水素結合を有していることから考えても決して不当で はない。このよらな場合, アミド間の水素結合の程度が 水の溶解性に影響してくることは当然予想されるところ である。

ナイロン 66 上 6 の共重合物（カプロラクタム 2 モルナ イロン塩 1 モル)をつくり, その水溶解度を測定した。 $235^{\circ} \mathrm{C}, 400 \mathrm{mmHg}$ の水蒸気圧で $0.32 \%, 600 \mathrm{mmHg}$ で $0.37 \%$ ，また $256^{\circ} \mathrm{C}, 400 \mathrm{mmHg}$ で $0.20 \%$ であった。 $235^{\circ} \mathrm{C}$ の值は同条件のナイロン 6 よりも溶解度がかなり 高いが， $256^{\circ} \mathrm{C}$ では比較的近似している。これはアミド 間の水素結合の程度が水の溶解性に影響していることを 
示すものと思われる。

Table 1 に水の溶解度とアミドの濃度の関倸を示し た。 $235^{\circ} \mathrm{C}$ ではアミドの濃度の 2 乗と 1 乗の中間に位し ている。しかし $255^{\circ} \mathrm{C}$ になると,アミドの濃度の 2 乗に 比例するようになる。水分子はアミド 2 個に対し 1 個の 割合で結合しているものとすれば， $235^{\circ} \mathrm{C}$ では水素結合 がかなり残っており， $255^{\circ} \mathrm{C}$ ではアミド閒の水素結合が 大分少なくなっているものと考えれば，一応の説明は つく。

Table 1 Relationship between Solubility of water and concentration of amide

\begin{tabular}{|c|c|c|c|}
\hline $\begin{array}{l}\text { Temp. } \\
\left({ }^{\circ} \mathrm{C}\right)\end{array}$ & Type of nylon & $\frac{(W)(M)}{\left(p_{w}\right)(b)}$ & $\frac{(W)(M)^{2}}{\left(p_{w}\right)(b)^{2}}$ \\
\hline 235 & nylon 6 & $6.06 \times 10^{-4}$ & $6.85 \times 10^{-2}$ \\
\hline " & " 610 & $5.70 \times 10^{-4}$ & $8.13 \times 10^{-2}$ \\
\hline " & " 11 & $5.31 \times 10^{-4}$ & $9.21 \times 10^{-2}$ \\
\hline 256 & nylon 6 & $4.64 \times 10^{-4}$ & $5.25 \times 10^{-2}$ \\
\hline " & " 610 & $3.89 \times 10^{-4}$ & $5.49 \times 10^{-2}$ \\
\hline " & " 11 & $2.56 \times 10^{-4}$ & $4.70 \times 10^{-2}$ \\
\hline
\end{tabular}

$W$ : Solubility of water weight per cent

$p_{w}$ : Vapor pressure of water $(\mathrm{mmHg})$

$M$ : Molecular weight of structural unit

$b$ : Dibasic acid-diamine type polyamide $b=2$ $\omega$ - amino acid type polyamide $b=1$

このように考えると, 水分子の見かけの蒸発熱が前 報6) で述べたように $16.3 \mathrm{kcal} / \mathrm{mol}$ と異常に高い事実も
ある程度妥当性をもつに至る。水分子 1 個に対し， 2 個 のアミドが水素結合に関与していることは室温付近のポ リアミドについて坪井らが認めており5，またポリアミ ドのアミド間の水素結合が溶融後も温度とともに連続的 に減少してゆくといわれているから，上述の解釈も定性 的には不当と思われない。

\section{2 縮合平衡について}

酶酸 $1 / 200$ モルを用いて縮合したナイロン 610 につい て $256,245,235^{\circ} \mathrm{C}$ に㧍いて $400 \sim 600 \mathrm{mmHg}$ の水蒸気 圧下に 6 時間扔いた後，アミノ末端基とカルボキシル末 端基を測定した (Table 2)。

縮合の平衡定数 $K_{c}$ は $256^{\circ} \mathrm{C}$ で平均 $293,245^{\circ} \mathrm{C}$ で $372,235^{\circ} \mathrm{C}$ で 477 となり,ポリカプラミドのときと同様 縮合の温度が低くなると平衡定数が大きくなる傾向があ り，また平衡定数の值もポリカプラミドと大体近似して いる。しかしこの実験に扔いて水蒸気压が低い方が平衡 定数がやや低い值を示している。この理由はカルボキシ ル末端基の測定值のばらつきが大きいことと, ポリカプ ラミドのときより水の溶解度が少なく, 完全な平衡に到 達するにはやや時間が不足であったことを示すものと思 われる。ナイロン 610 の $235^{\circ} \mathrm{C}, 400 \mathrm{mmHg}$ の水蒸気圧 下に扔ける粘度, 末端基, 重合度などの時間的变化を測 定した。使用したポリマーは粘度安定剤として酢酸 1 / 200 モルを用いている(Table 3)。

もし水の溶解平衡がきわめてただちに行なわれている とすれば, $n_{w}$ は常に一定であるから見かけの縮合の平衡

Table 2 Nylon 610: Equilibrium constent between the linear polymer and water

\begin{tabular}{c|c|c|c|c|c|c}
\hline \hline $\begin{array}{c}\text { Temp. } \\
\left({ }^{\circ} \mathrm{C}\right)\end{array}$ & $\begin{array}{c}\text { Vapor pressure } \\
\text { of water } \\
(\mathrm{mmHg})\end{array}$ & $-\mathrm{NH}_{2}$ (mole) & $-\mathrm{COOH}(\mathrm{mole})$ & $n_{w v}$ & $K_{c}$ & Average \\
\hline 256 & 600 & 0.00783 & 0.02083 & 0.0259 & 317 & 293 \\
$\prime \prime$ & 400 & 0.00627 & 0.02057 & 0.0173 & 269 & \\
245 & 600 & 0.00743 & 0.02029 & 0.0306 & 405 & 372 \\
$\prime \prime$ & 400 & 0.00603 & 0.02010 & 0.0204 & 338 & \\
235 & 600 & 0.00722 & 0.02096 & 0.0384 & 508 & 477 \\
$\prime \prime$ & 400 & 0.00588 & 0.02009 & 0.0256 & 435 & 473 \\
\hline
\end{tabular}

Table 3 Nylon 610: Variations of end groups and solution viscosity with time

\begin{tabular}{c|c|c|c|c|c|c}
\hline \hline Time (hr) & $-\mathrm{NH}_{2}(\mathrm{~mol})$ & $-\mathrm{COOH}(\mathrm{mol})$ & $\bar{P}_{n}$ & $n_{w}$ & $K_{c}$ & {$[\gamma]_{\text {cresol }}^{25}$} \\
\hline 0 & 0.0136 & 0.0284 & 42.6 & 0.0256 & - & 1.016 \\
1 & 0.00871 & 0.0231 & 54.3 & $\prime \prime$ & 254 & 1.197 \\
2 & 0.00787 & 0.0219 & 57.5 & $\prime \prime$ & 297 & 1.264 \\
3 & 0.00715 & 0.0221 & 58.5 & $\prime \prime$ & 324 & 1.332 \\
5 & 0.00605 & 0.0208 & 62.8 & $\prime \prime$ & 406 & 1.349 \\
6 & 0.00588 & 0.0201 & 64.6 & $\prime \prime$ & 435 & 1.355 \\
10 & 0.00663 & 0.0209 & 61.5 & $\prime \prime$ & 368 & 1.362 \\
\hline
\end{tabular}


定数は時間の経過とともに大きくなっていく。 $n_{w}$ には

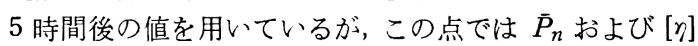
がほとんど安定しているから, 水の溶解量もほぼ平衡量 に到達している。約 6 時間水蒸気に接触せしめれば十分 ではないが，大体の平衡定数が測定できるはずである。

\section{3. 結言}

ポリアミドの重合条件の選定にはかかる平衡理論が忘 用でき, 水の平衡溶解量がポリアミドの種類によって異 なるから，これを考虑に入れて条件を選定すれば良い。

付 記：ご指導拉よび発表許可を賜わった東洋レーヨン
(株)名古屋工場長菊川康雄氏，研究部長小林治男博士に謝意を 表します。

$$
\text { 文献 }
$$

1) 福本 修: 高化, 18, 22(1961)

2）星野孝平, 由本碩亮：東洋レーヨン集報, 1,137 (1949)

3) O. Fukumoto: J. Polymer Sci., 22, 263(1956)

4) R. Huisgen : Chem., Ber., 89, 2616(1956)

5) 坪井正道：Bull. Chem. Soc. Japan, 25, 160 (1952)

6) 福本 修: 高化, 18, 19(1961)

\section{Equilibria Between Polycapramide and Water}

\section{Nylon 6, Nylon 610, Nylon 11}

\section{By Osamu Fukumoto*}

This investigation deals with the relationships between the solubility of water in the molten nylon 6,610,11 and its vapor pressure. The experimental results indicate that intermolecular hydrogen bonds are still remained at comparably lower temperatures (above melting point), and however the number of these hydrogen bonds becomes very few at higher temperatures (for instance, at $256^{\circ} \mathrm{C}$ ). The equilibrium constant in polycondensation of nylon 610 is calculated from the results of titration of the end groups. This equilibrium constant decreases with the rising temperature. These results resemble closely to those for nylon 6 . 